\title{
REFLECTIONS ABOUT PUBLIC PROPERTY IN THE ROMANIAN CONSTITUTIONAL SYSTEM AND COMPARATIVE LAW - SELECTIVE ASPECTS \\ Nicolae PAVEL
}

\author{
"Spiru Haret" University, Bucharest, Romania \\ e-mail nicolaepavel0@yahoo.com
}

\begin{abstract}
What seems relevant for the present study to highlight is the approach evolving reflections about public property in the Romanian constitutional system and comparative law.

The subject of the scientific endeavour will be circumscribed to the scientific analysis of its parts, as follows: 1) Introduction. 2) Identification of constitutional rules on public property in Romanian constitutional system and comparative law. 3) Highlights of Romanian doctrine and comparative law on public property. 4. Highlights of jurisprudence regarding public property. 5) Conclusions.
\end{abstract}

Keywords: public property, Romanian constitutional system, comparative law, highlights Romanian doctrine, Highlights jurisprudence

\section{Introduction}

1.1. As results of bibliographic research carried out, public property is new in point of formulation, but it is not new in point of existence. Starting from this axiom, and, paraphrasing M'Baye, [1] we may say that: „The history of public property merges with the history of humankind".

Theorizing property under its various aspects goes back in time to Aristotle [2] who in Chapters III, IV, and V, of Book I, entitled „On the state, On slavery, On property", analyses some aspects related to the state and to property.

The state as a political association is approached by Aristotle (384 B.C. - 322 B.C.), the founder of political science, Plato's disciple and illustrious philosopher of the Antiquity and of ancient Greece. In his famous work Politics the slave cities known by the author are described, compared, identified and classified for the purpose of highlighting the similarities and the differences between them, or the existence of identical, consistent, inconsistent or divergent and of course, certain visionary remarks on their ideal evolution.

Aristotle considers that: any state is a kind of association and any association is set up for some purpose (because for what they think is good, everybody does everything), it is clear that all of them (associations) converge to some good, and this purpose is fulfilled as consummate as possible and tends to the more exquisite good that association which is the most consummate of them all and includes them all. This is the so-called state and the political association.

In Book IV entitled Ideal Republic, Aristotle resumes his theory described above, acknowledging for the slaves on public land the capacity of human beings supporting their release from slavery as follows: on private pieces of land, they will belong to the landlord, on public lands will be of the State. 
We will detail later on how we can behave with the slaves and why we should put before their eyes freedom as the price of their work.

Moreover, according to Aristotle's political theory, he who participated in the exercise of public powers was considered a citizen.

As a conclusion of the above-said, Aristotle shaped for the first time by the theory stating that on public pieces of land, the slaves will belong to the state, the components of the modern theory on public property.

1.2. The first constitutional regulations, which in our opinion, setting the extension of public property sphere, implicitly set also guarantees on private property were identified in the normative content of the first written constitutions of the world, as follows: a) the Constitution of the United States of America of 1787, [3] the normative content of Amendment $\mathrm{V}$, to the Constitution, entitled "Protection of the rights to life, freedom and property" define the following principles: „No person can in a criminal case be deprived of life, freedom or property without following the natural course of trial law; no private property can be taken over for public interest without fair compensation". b) the Constitution of France of 3 September 1791, [4] in Title I, entitled „Fundamental provisions guaranteed by the Constitution" defines the following principle: „The Constitution guarantees the inviolability of properties, or their just and previous compensation, whose sacrifice would be claimed by the legally found public utility".

1.3 From comparative law, in constitutional matters, we selected for this study the Constitution of France „The full text of the Constitution of 4 October 1958 effective on the date of constitutional revision of 23 July 2008" and the Constitution of Belgium „The text of the Constitution of Belgium of 17 February 1994, as supplemented with the constitutional revisions until 12 March 2014", because in our opinion, these constitutions contain the most recent revisions.

1.4. In our opinion, the studied field is important for the doctrine in the line of public and private law in the matter, as well as for practitioners of law, because we intend by this scientific approach to consider selectively a complex and complete reflection, but not exhaustive of the current sphere of public property.

1.5. Even if theorizing public property in the Romanian constitutional system and in comparative law can be found in doctrine, the theoretical interest for resuming it is determined by the fact that in specialized literature the three normative, theoretical and jurisprudential aspects on public property have not always been considered properly.

2. Identification of constitutional rules on public property in the Romanian constitutional system and comparative law. 2.1. Identification of constitutional rules on public property in the Romanian constitutional system.

A different discussion is required in relation with The developing Statute of the Convention of 7/19 August 1858. [5]

The systematic analysis of the normative content of the Statute of the normative content of the State, the following aspects are worth mentioning: a) The Statute may, in our opinion, be considered a Constitution, considering the provisions of art. XVII stating that: All civil servants, with no exception, on taking office are found to swear allegiance to the Constitution and laws of the country and faith in God. b) The Statute contains no provision related to public property.

\subsubsection{The Romanian Constitution of 1866 [5]}

The systematic analysis of the normative content of the Constitution shows that in the content of Title II, entitled On the rights of the Romanians defines for the first time in the constitutional history of Romania the property of any kind, in the normative content of art. 19, which in the matter, sets the following fundamental principles: 1 . 
Property of any kind, and all the claims against the State are sacred and inviolable. 2. Nobody can be expropriated except for cause of legally found public utility and after just and prior compensation. 3. Special laws shall regulate the procedure and the mode of expropriation.

In our opinion, the syntagm "Property of any kind" includes also public property, which is proclaimed "sacred and inviolable". Moreover, we find that fundamental law proclaiming as "sacred and inviolable property of any kind", also sets the appropriate guarantees related to private property, and regulates expropriation, and the procedure and the mode of expropriation.

\subsubsection{The Constitution of Romania of 1923 [5]}

The systematic analysis of the normative content of the Constitution shows that, in the content of Title II, entitled On the rights of the Romanians, defines which in the matter sets the following fundamental principles: 1. Property of ay kind and the claims against the State are guaranteed. 2. Nobody can be expropriated unless it is for a cause of public utility and after a just and prior compensation determined by justice. 3. A special law shall determine the public utility cases, the procedure and the mode of expropriation.

From our point of view, the syntagm "Property of any kind" includes also public property that the Constitution "guarantees". On the other hand, we find that fundamental law when proclaiming as "sacred and inviolable the property of any kind" also sets the appropriate guarantee on private property, regulating the fundamental principles on expropriation except for a public utility cause after a just and prior compensation as well as setting by law the public utility cases, the procedure and the mode of expropriation

\subsubsection{The Constitution of Romania of 1938 [5]}

The systematic analysis of the normative content of the Constitution shows that in
Chapter II, Title III, entitled On the rights of the Romanians, defines inviolability and the guarantee of property of any kind in the normative content of art. 16, which in the matter, sets the following fundamental principles: 1. Property of any kind, and the claims against the private persons and against the State are inviolable and guaranteed as such. 2. No law can establish the penalty of forfeiture of assets, except for the cases of high treason and embezzlement of public money. 3. Nobody can be expropriated except for a cause of public utility and after just and prior compensation as set by the court under the laws.

In our opinion, the syntagm "Property of any kind" includes also public property, which according to the Constitution is inviolable and guaranteed as such.

Moreover, we find that fundamental law procaiming as "sacred and inviolable the property of any kind", also sets the appropriate guarantees, on private property, regulating the fundamental principles according to which: a) No law can establish the penalty of forfeiture of assets, except for the cases of high treason and embezzelment of public money. b). Nobody can be expropriated except for a cause of public utility and after just and prior compensation as set by the court under the laws.

2.1.4. The constitutional development of Romania followed in 1944 until the adoption of the Constitution of 13 April 1948. The Constitution of 24 September 1952 and of the Constitution of 21 August 1965 was adopted successively, as further amended. „The interval between, 19521965 was characterized by the extension of state and cooperative property, the abolition of private property, emphasis on leadership not only political, but also state leadership by only one political party, the communist party, which held the monopoly of state politics and society. A new Constitution was adopted on 21 August 1965". [6]

2.1.5. The Constitution of 21 August 1965, as republished on 29 October 1986 
[5] has the following normative content and regulates the fundamental social relations in the Romanian society, and is structured according to 9 distinct titles, as follows: Title I (Socialist Republic of Romania). Title II (Citizens' fundamental rights and duties). Title III (Supreme bodies of state power). Title IV (Central bodies of state administration). Title $\mathrm{V}$ (Local bodies of state power and local bodies of state administration). Title VI (Judicial bodies). Title VII (Prosecution). Title VIII (Insignia of the Socialist Republic of Romania). Title IX (Final provisions).

„The constitutional provisions established the republican form of the state, the sovereignty and independence, indivisibility and inalienability of the territory. As for the holder of power, it is specified that this is the people. Besides such provisions Title I of the Constitution includes provisions on the forms of property, state functions, principles of foreign policy, citizenship and administrative organization of the territory".[6]

2.1.6. The Constitution of Romania as revised in 2003, the republished form of the Constitution of Romania of 1991[7]

The systematic analysis of the normative content of the Constitution of Romania, as revised in 2003, shows that in the content of Title IV, entitled Economy and public finance, defines public property in the normative content of art. 136, which in the matter, sets the following fundamental principles: 1. Property is public or private. 2. Public property is guaranteed and protected by the law and it belongs to the state or to the administrative-territorial units. 3. Public riches of the underground, the air, waters with energy potential of national interest, the beaches, the in-land sea, the natural resources of the economic area and the mainland, as well as other assets set out by organic law make the exclusive object of public property. 4 . The public property assets are inalienable. Under the terms of organic law, they may be contracting out to autonomous administrations or public institutions or may be regies autonome or public institutions or may be leased or rented; moreover, they may be given on gratuitous loan for use to public utility institutions. 5 . Private property is inviolable, under the terms of organic law.

Concerning the marginal synthesis of the normative content of article 136, Property, in our opinion, the following were considered: a) it was intended to highlight the economic nature of its content, conferring thereby a value of maximum generality of the content. b) the abovementioned constitutional principles were developed by adopting and „Law nr. 214 of 17 November 1998 on private property and its legal regime" [8], whose title and content, of course, show that such law includes two large parts: 1. Pubic property. and, 2. Legal regime. c) the analysis of the normative content of the law shows that it includes two Chapters with normative content, respectively: a) Chapter I entitled General provisions and, b) Chapter II, entitled the legal regime of public property, where in our opinion, the five fundamental principles set out by article 136 of the Constitution of Romania, as revised in 2003.

\subsection{Identification of constitutional regulations on public property in comparative law}

2.2.1. The full text of the Constitution of 4 October 1958 effective on the date of the constitutional revision of 23 July 2008, [9] as specified contains the most recent revisions.

The systematic analysis of the Constitution of France shows that the following documents were inserted between ,the content of the Constitution", which begins the text and its ,Preamble': 1. The Declaration of Human and the Citizen's Rights of 1789. 2. The Preamble of the Constitution of 27 October 1946. 3. The Environment Charter of 2004.

These three documents form in the current French constitutional system the so-called 
constitutional block. The analysis of the normative content of the documents mentioned in the constitutional block shows that only The Declaration of Human and the Citizen's Rights of 1789 contains the following norms which regulate expressis verbis, ,property”: article. 2, „The purpose of any political association is the preservation of natural and imprescriptibly rights of man. These rights are freedom, property, safety and resistance to oppression”: art. 17 ,As property is an inviolable and sacred right, nobody can be deprived of his/her property, except when the legally found public necessity requires evidently and under the terms of a just and prior compensation".

In our opinion, the syntagm "As property is an inviolable and sacred right" is included also public property, which has the same protection of constitutional value.

2.2.2. The text of the Constitution of Belgium of 17 February 1994, with the constitutional revisions until 12 March 2014, [10] as specified, contains the most recent revisions.

The systematic analysis of the Constitution of Belgium shows that, in Title II, entitled On Belgians and their rights sets forth the following constitutional on property, in the normative content of the following articles: 1. article. 16. Nobody can be expropriated unless for a public utility cause, in the cases and under the procedure set by the law, in exchange of a just and prior compensation. 2. article. 17. The penalty of forfeiture of assets cannot be determined.

The above-mentioned principles show, from out point of view, that the constitutional text sets the appropriate guarantees for public property also.

\section{Highlights of Romanian doctrine and comparative law on public property.}

3.1 Highlights of Romanian doctrine on public property.

We should acknowledge since the very beginning that in the Romanian constitutional doctrine there were a lot of approaches on property and implicitly on public property.

Concerning the content of current regulations of article 136 of the Constitution, in Romanian constitutional doctrine, we retain the following: [11] „The five paragraphs contain three categories of provisions: a) in relation with the basic typology of the property system, b) in relation with the basic principles of public property c) in relation with the fundamental principle of public property."

Moreover, in relation with the content of current regulations of article 136 of the Constitution, in the Romanian administrative doctrine, we acknowledge the following: [12] „Thus, article 136 of the republished Constitution, after finding the two forms of property (public or private), sets forth that public property is guaranteed and rotected by the law and establishes the holders of pubic ownership, sample lists public property assets, expressly mentioning their fundamental characteristic feature to be inalienable and the fact that they may be contracted out to autonomous administrations or public institutions, may be leased or rented and may be given for gratuitous use to the public utility institutions, and finally to instate the principle of inviolability of public property, under the terms of organic law."

3.2 Highlights of comparative law on public property.

We selected from the Belgian doctrine for this research the study on private property made by Professor Francis Delpérée. [13] Concerning the „The regime of assets and property", the author presents the following aspects: 1. The regime of assets and property organized by public law could not confound with that organized by the Civil Code, in particular its art. 544. 2. Property, according to civil law, may be limited for use by the law or regulations. 3. But property, according to public la - i.e. real property -, may in addition and for a cause of public utility just be taken away". 4. Any damage to property shall not become 
expropriation. 5. „Expropriation can occur only under the terms of article. 16 of the Constitution, for the cause of public utility. The notion is genera; and its contours are imprecise.

We selected from the French doctrine for this research the study on private property made by Professor Claude - Albert Colliard. [14]

Concerning the "The theory of ownership" the author presents the following aspects: 1 . In relation with the relationship between property and public law, the author specifies: ,the ownership analyzed from the point of view of a civil right as a subjective right which allows any individual to exercise over an asset an operating monopoly and impose its observance against everybody, takes another aspect in public law 2. In relation with the alleged aspect of the ownership, by simply rereading art. 544 of Civil Code, so frequently presented as an expression of the ownership absolutism, it may be found that it means in no way what it traditionally presents, i.e. property represents the right to enjoy and suppose of things in the most absolute way, provided it should not turn it into a use prohibited by the law and regulations".

\section{Highlights of Romanian jurisprudence on public property}

4.1.The Decision of the Constitutional Court no. 600/2005 [15] in relation with the constitutionality of the Law for the regulation of the legal situation of some assets which belonged to the ex-sovereign of Romania, Mihai I.

The authors of the intimation request the Constituional Court the exercise of judicial control over the „Law for the regulation of the legal status of some goods which belonged to the former sovereign of Romania, Mihai I" consisting in the breach of the provisions of art. 1 par. (1) and (3), art. 4 alin. (2), art. 16 par. (1) and (2), art. 44 par. (1) şi (2), art. 136 pr. (4) and of art. 137 par. (2) of the Constitution.

The Court acknowledges that „considering the undisputable juridical reality instated by the law, in the sense that the assets belonging to the Peles domain are part of the state-owned public property, the Court considers that the gratuitous use of Peles Castle, of Pelisor Castle and of Foisor Castle to the former sovereign of Romania, even with the circumstantiation established by let. b) of art. 4 of the law, violates the provisions of art. 136 par. (4) thesis III of the Constitution, according to which the public property assets may be given for gratuitous use to the public utility institutions. Even by accepting that the former king is legally authorized to carry on such an activity, it does not legitimize, in the terms of the constitutional test of reference, the assignment of gratuitous use of the concerned buildings, as long as the holder is not a public property institution."

The same reasons also impose a similar conclusion concerning the provision having as object the granting of a gratuitous right for user of Elisabeta Palace in favor of Princess Margareta and Prince Radu.

For the above-mentioned reasons, the Court finds that the Law for the reglementation of the equal status of some assets which belonged to the former sovereign of Romania, Mihai I, is unconstitutional.

4.2. The Decision of the Constitutional Court no. 146/2013 [16] on the exception of unconstitutionality of the provisions of art. 29 par. $\left(3^{\wedge} 1\right)$ of Law no. $1 / 2000$ for the restitution of land rights of the farming and forest land claimed under the provisions of the Land Law no. 18/1991 and of Law no. $169 / 1997$

In motivation of the exception of unconstitutionality it is stated that, as per art. 136 par. (3) final thesis and par. (4) of the Constitution, the assets which, under the organic law, make the exclusive object of public property, may be given for gratuitous use of public utility institutions.

Whereas, the motivation of the exception of unconstitutionality, and under art. 62 first thesis of Law no. 24/2000 on the rules of legislative technique for the elaboration of the normative acts, as republished in the 
Official Journal of Romania, Part I, no. 260 of 21 April 2010, the Court finds that the object of exception of unconstitutionality is the provisions of art. 29 par. (31) of Act no. $1 / 2000$ for the restitution of the ownership of farming and forest land, claimed under the provisions of Land Law no. 18/1991 and of Law no. 169/1997, as amended by article. I item. 1 of Law no. 261/2008.

Thus, by Decision no. 983 of 22 Novembre 2012, published in the Official Journal of Romania, Part I, no. 5 of 4 January 2013, the Court dismissed as unfounded the exception of unconstitutionality, stating that, under art. 1 of Law no. 61/1937, the term ,endowment" in the title of Law no. $61 / 1937$ had the meaning of granting ,for full and perpetual use."

For the above reasons, the Court dismissed as unfounded the exception of unconstitutionality of the provisions of art. 29 par. (31) of Law no. 1/2000 for the restitution of ownership of the farming and forest land, claimed under the provisions of the Land Law no. 18/1991 and of Law no. $169 / 1997$.

\section{Conclusions}

1. As results of bibliographic research carried out, public property is new in its formulation, but, it is not new in its existence. Starting from this axiom, and paraphrasing $M^{\prime}$ Baye, we may say that: „The history of property is confounded with the history of human beings".

2. Theorizing property under its various aspects goes back in time to Aristotle.
3. The first constitutional regulations on property were identified in the normative content of the first constitution of the world, i.e.: the Constitution of the United States of America of 1787 and the Constitution of France of 3 September 1791.

3 . In the Romanian constitutional system the regulations were fully identified on public property since the first document with constitutional value for the Romanians, the Developing Statute of the Convention of 7/19 August 1858, until the current Constitution of Romania as revised in 2003, the republished form of the Constitution of Romania of 1991.

4. We selected from the field of comparative, in constitutional matter, for this research the Constitution of France „The full text of the Constitution of 4 October 1958 effective on the date of constitutional revision of 23 July 2008" and the Constitution of Belgium ,The text of the Constitution of Belgium of 17 February 1994, as supplemented with the constitutional revisions until 12 March 2014", because these constitutions, in our opinion, contain the most recent revisions.

6. The Romanian and French dictionary studies in the matter of public property were identified, which forms our point of view, are the most read in the matter.

7. We presented from the Romanian constitutional jurisprudence the decisions of the Constitutional Court of Romania, the most recent, and in our opinion, the most meaningful in the matter.

\section{References}

[1] M'Baye, Les droits de l'homme et des peuples, Paris, Edition A. Pedone, 1991, p. 111.

[2] Aristotel, The policy, Filipeştii de Târg, Prahova, Romania, Antet XX Pres Publishing House, 2009, pp. 69-79, 102.

[3] Tănăsescu, , Simina, Elena, and Pavel, Nicolae, Constitution of the United States of America, Bucharest, All Beck Publishing House, 2002, p. 73.

[4] Charles Debbasch, Jean-Marie Pontier, les Constitutions de la France, Paris, Dalloz, 1983, p. 11.

[5] Muraru, Ioan, and, Iancu, Gheorghe, Texts, Notes, Comparative Presentation, Bucharest, Actami Publishing House, 2002, pp. 7-28, 29-60, 61-92, 95 -119, 169-198.

[6] Muraru, Ioan, and Tănăsescu, Simina, Elena, Constitutional Law and Political Institution, Ed. 4, Volume I, Bucharest, C. H. Beck Publishing House, 2011, pp. 97, $97-$ 
98.

[7] The Constitution of Romania, revised in 2003, was published in the Official Gazette of Romania, Part. I, no. 767, of October 31, 2003.

[8] The Law no. 214 of November 17, 1998, on public property and its legal regime, was published in the Official Gazette of Romania, Part. I, no. 448, of November 24, 2008.

[9] http://www.conseil-constitutionnel.fr/...constitutionnel...

[10] La Constitution Belge, mai, 2014, Chambres des Représentants, Service juridique de la Chambre des Représentants.

[11] Constantinescu, Mihai, and Iorgovan, Antonie and Muraru, Ioan, and Tănăsescu, Simina, Elena, The Constitution of Romania, Comments and explanations, Bucharest, ALL Beck Publishing House, 2004, p. 292.

[12] Tofan, Apostol, Dana, Administrative Law, Volume II, Ed. 2, Bucharest, C. H. Beck Publishing House, 2009, p. 113.

[13] Francis Delpérée, Le Droit Constitutionnel De La Belgique, Edition Bruylant, Bruxelles, et Librairie Générale de Droit, Paris, 2000, pp. 249 - 253.

[14] Claude - Albert - Colliard, Libertés publiques, Septième édition, Dalloz, Paris, 1989, pp. $835-858$.

[15] Decision of the Constitutional Court of Romania, nr. 600 of November 9, 2005, was published in the Official Gazette of Romania, Part. I, no. 1060, of November 26, 2005.

[16] Decision of the Constitutional Court of Romania, nr. 146 of March 7, 2013, was published in the Official Gazette of Romania, Part. I, no. 182, of April 2, 2013. 